\title{
NEW LIGHT ON LITERACY \\ IN EIGHTH-CENTURY EAST ANGLIA: A RUNIC INSCRIPTION FROM BACONSTHORPE, NORFOLK
}

\begin{abstract}
An object inscribed with Anglo-Saxon runes recently found in East Anglia is tentatively identified as an artefact associated with the use of manuscripts: a page-holder or page-turner. The well-formed and elegant inscription allows us to identify a hitherto unrecognized runic graph in the Anglo-Saxon tradition as well as a previously unrecorded inflected form of the Old English verb cunnan. The find constitutes rich and special evidence of the development of a literate culture in Anglo-Saxon England, and in particular of the relationship between runic and Roman literacy in the later eighth century.
\end{abstract}

\section{THE FIND}

Towards the end of May 2009, an item bearing a runic inscription was found during archaeological excavations in the parish of Baconsthorpe, Norfolk (Fig. 1). The archaeological fieldwork was being conducted along the line of a cable-trench associated with an off-shore wind-farm development. The inscribed object was discovered through a metal-detector scan of the surface of the subsoil after the uppermost layer of topsoil had been removed by machine. The object cannot be associated directly with any specific archaeological context. Roman-period structural remains were identified close by, but there are no other Anglo-Saxon or later medieval features or finds from this site.

The forms of the runes are discussed in detail below, but it may be noted at the outset that, with the partial exception of one remarkable graph that occurs three times in the inscription, the runes are entirely consistent with what we are familiar with the Anglo-Saxon (sometimes called 'Anglo-Frisian') fuporc. They include one clear and one inferred example of $F, \bar{a} c$, an innovation characteristic of this branch of runic writing. ${ }^{1}$

1 There has been some debate over the circumstances and dating of this development: John Hines, "Some Observations on the Runic Inscriptions of Early AngloSaxon England", Old English Runes and their Continental Background, ed. Alfred Bammesberger (Heidelberg: Winter, 1991) 61-83, at 80-2; Hans Frede Nielsen, "The Emergence of the os and ac Runes in the Runic Inscriptions of England and Frisia: a Linguistic Assessment”, Friesische Studien II, ed. Volker F. Faltings et al. (Odense: Odense UP, 1995) 19-34; David N. Parsons, Recasting the Runes: The Reform of the Anglo-Saxon 'Futhorc' (Uppsala: Institutionen för nordiska språk, 1999) 34-8. 


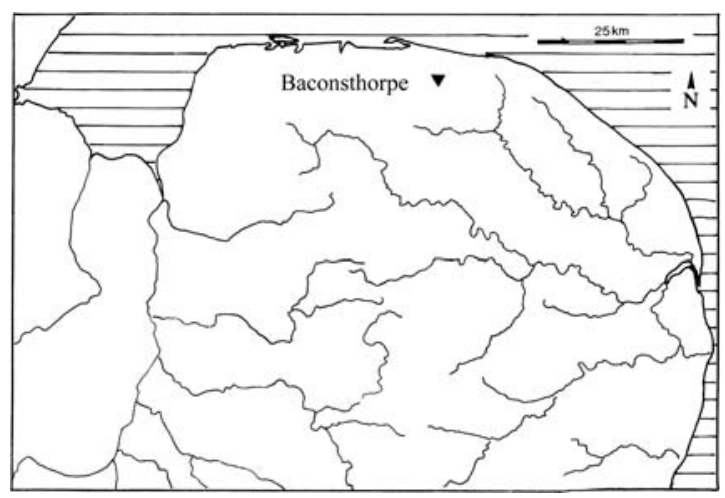

Fig. 1: Site location

The inscribed artefact is a flattened rod of hammered copper alloy with a spatulate head (Fig. 2). The rod survives to a length of c. $35 \mathrm{~mm}$, now bent over. It tapers slightly away from the head, but is around $5 \mathrm{~mm}$ wide. The spatulate head is a trapezoid, $18 \mathrm{~mm}$ long and $18 \mathrm{~mm}$ at its greatest width. One face of the head is decorated with punchmarks along both edges. Its wide end is neatly curved over, implying that the object was designed to grip something, and is decorated with fluted moulding.

Similar artefacts have been found at the 7th- to 9th-century Anglo-Saxon monasteries of Whitby, N. Yorks., Monkwearmouth and Hartlepool, Co. Durham, where they are identified as tweezers, and perhaps more specifically as page-holders or page-turners. ${ }^{2}$ Such specialized artefacts are more familiar from quite late medieval contexts, including Chester, Northampton, Norwich, Old Sarum, Winchester and Byham Abbey. ${ }^{3}$ Besides their association with what must have been centres of literacy, the putative Anglo-Saxon specimens all have wide heads, which would put light and

2 Whitby: Charles R. Peers \& Courtenay A. Ralegh Radford, “The Saxon monastery of Whitby", Archaeologia 89 (1943): 27-88, at 61-3, fig. 13, esp. items 5, 9 and 13; Monkwearmouth: Rosemary J. Cramp, Wearmouth and Jarrow Monastic Sites (Swindon: English Heritage, 2007) 2: 246: object CA116; Hartlepool: Robin Daniels, Anglo-Saxon Hartlepool and the Foundations of English Christianity (Hartlepool: Tees Archaeology, 2007) 124-5.

3 Martin Biddle, Object and Economy in Medieval Winchester (Oxford: Clarendon P, 1990) 2: 756-7; Philip A. Emery et al., Norwich Greyfriars: Pre-Conquest Town and Medieval Friary, East Anglian Archaeology 120 (Norwich, 2000) 143-4. The specimen originally published as a find from the Early Anglo-Saxon cemetery of West Stow, Suffolk is one of a number of unfamiliar artefacts dating as late as the sixteenth century that have somehow become included in this Victorian collection of Anglo-Saxon finds: Stanley E. West, West Stow: The AngloSaxon Village. East Anglian Archaeology 24 (Ipswich, 1985) Vol. 2, fig. 264.1112. 

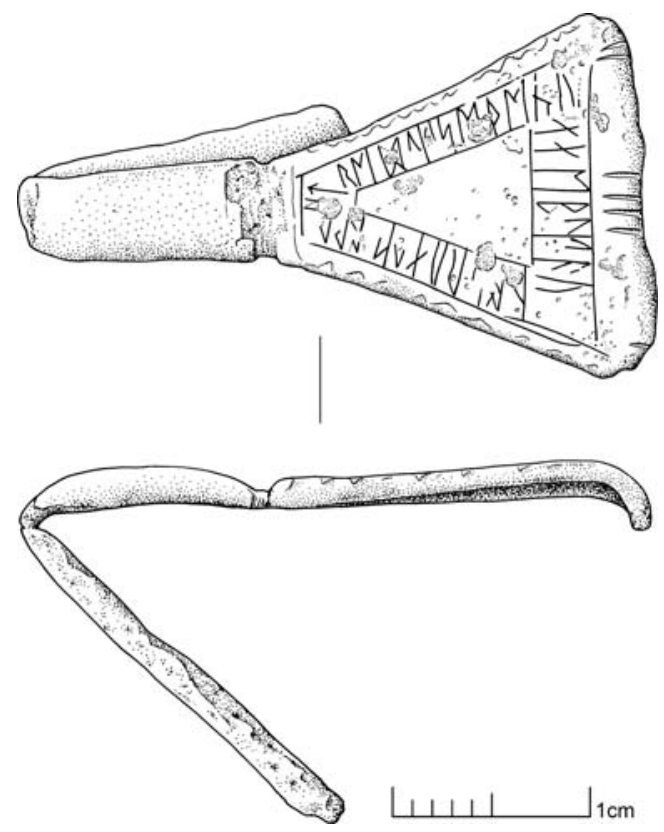

Fig. 2: The inscribed artefact from Baconsthorpe, Norfolk. Scale 2:1. Drawn by David Dobson. () NAU Archaeology.

diffused pressure on the object gripped, not a concentrated, cutting force; the arms of the Baconsthorpe clip also provide rigidity rather than spring. The possibility that this object had a literary function is of especial interest in relation to the form and contents of the runic inscription. This functional identification is a realistic one; it is important, however, to stress that as yet it remains conjectural. Tweezers with broad heads are characteristic of the 8th century in England and on the Continent; the arm of the Baconsthorpe object, however, is quite distinctive.

\section{THE INSCRIPTION}

The inscription (Fig. 3) is laid out around the edge of the head, between incised parallel frame-lines. From one corner, the outer frame-line has been cut twice, to follow a slightly different line. The area within which the inscription had to be fitted is small, and the runes themselves are tiny and very finely inscribed: the shortest slightly under $2 \mathrm{~mm}$ high; the tallest no more than $2.8 \mathrm{~mm}$. The direction of writing is left-to-right, but there is no identifiable mark showing where the text begins, nor any sign of word-division. A number of the runes are obscured by corrosion that has caused some pitting of the surface of the copper alloy but there is usually 


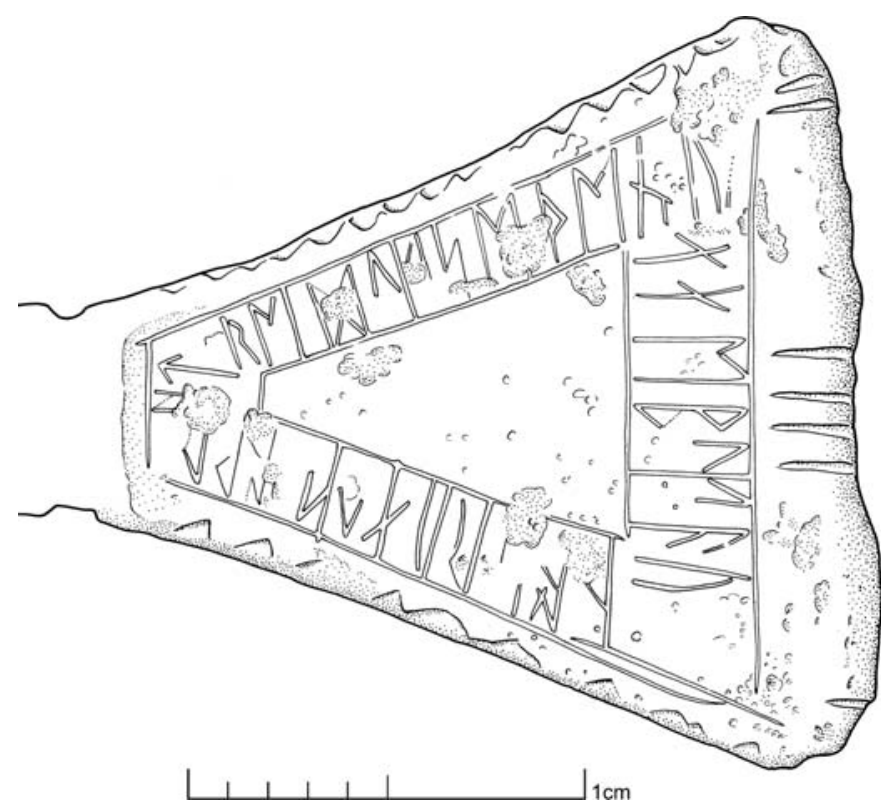

Fig. 3: The inscribed head of the artefact. Scale 4:1. Drawn by David Dobson. (C) NAU Archaeology.

enough still visible for a confident identification of the rune originally inscribed. More problematic are cases where the runes have been cut unusually lightly or abrasion has made the staves fainter.

The inscription apparently consists of 30 runes (Fig. 4). These include one rune-form ' 4 ' occurring three times (nos. 4, 16 and 25), which for reasons explained below, I transliterate as ę, adapting Henry Sweet's transliteration of a variant graph for the Old English vowels $\propto$ and $\bar{\infty}{ }^{4}$ The transcription in Figure 4 starts at the left-hand side of one of the two longer lines of the inscription, adjacent to where the rod-shaft and terminal head join (see Fig. 3). This indeed proves to be where one of two sentences that make up the text of the inscription begins.

${ }^{4}$ Henry Sweet, The Oldest English Texts, EETS OS 83 (London: Oxford UP, 1957); Alistair Campbell, Old English Grammar (Oxford: Oxford UP, 1959) \$40; Richard M. Hogg, A Grammar of Old English (Oxford: Blackwell, 1992) $\$ 2,12$. In accordance with standard practice, transliterations of runes are given here in bold type; bind-runes (two graphs in ligature) are transliterated with a slash, /, between the individual graphs represented. Old English phonemes are represented in italics, and the usual square brackets [ ] are used for a phonetic symbol. Angled brackets, <>, denote graphemes. 


\begin{tabular}{|c|c|c|c|c|c|c|c|c|c|c|c|c|c|c|}
\hline 1 & 2 & 3 & 4 & 5 & 6 & 7 & 8 & 9 & 10 & 11 & 12 & 13 & 14 & 15 \\
\hline$R$ & $M$ & $\Delta$ & $\mu$ & 4 & $M$ & $p$ & $M$ & $h$ & $\Lambda$ & I & $t$ & t & M & $B$ \\
\hline $\mathbf{r}$ & e & d & ę & $\mathbf{s}$ & e & p & e & c & $\mathbf{u}$ & $\mathbf{i}$ & $\mathbf{n}$ & n & e & b \\
\hline 16 & 17 & 18 & 19 & 20 & 21 & 22 & 23 & 24 & 25 & 26 & 27 & 28 & 29 & 30 \\
\hline$\mu$ & $F$ & $\Lambda$ & $p$ & $r$ & 4 & $R$ & $\Lambda$ & $t$ & $\mu$ & $k$ & $p$ & $R$ & $F$ & $\uparrow$ \\
\hline ę & $æ$ & $\mathbf{u}$ & p & $\mathbf{a}$ & $\mathbf{s}$ & $\mathbf{r}$ & $\mathbf{u}$ & $\mathbf{n}$ & ę & a & $\mathbf{w}$ & $\mathbf{r}$ & a & $\mathbf{t}$ \\
\hline
\end{tabular}

Fig. 4: Identifications of the runes in the Baconsthorpe inscription: transliteration.

The majority of the identifications are unproblematic. Runes partially obscured by corrosion but where sufficient can be seen for unambiguous identification are nos. 3, 6, 19 and 21 .

Rune $9, h$, c, is quite clumsily formed, and it is impossible to be certain that the sloping cross-stave was intentionally cut as part of this rune. That line is indistinguishable to the eye, even under the microscope, from another deeper, wider and rounder scratch that runs almost parallel to it across the top of the main stave of this rune. The other clearly identifiable vertical staves here, however, can only form the c-rune.

Runes $10-11, \mathbf{N}$, ui. The $\mathbf{u}$-rune is partly obscured both by the definite scratch crossing the top of rune 9 just mentioned. A further vertical line, apparently incised with the same tool as used for the runes alongside the u-rune to the right but only visible for a short length, is here identified as an i-rune, I, on grammatical grounds explained below.

Runes 12,13 and 24 are identified as $\mathbf{n}, \nmid$, with the cross stave sloping down from right to left. This is unusual but paralleled in earlier Scandinavian and Continental inscriptions. ${ }^{5}$ A slight curvature in the vertical staves of the runes bowing towards the right implies that the inscriber was lefthanded, and this might explain the relatively unusual from of the $\mathbf{n}$. On rune 13 a fainter incised line joins the top of the main stave with the upper end of the crossing by-stave to its right, forming a triangle, as at the head of the w-rune, $P$. The lower by-stave, however, clearly cuts right

${ }^{5}$ Bengt Odenstedt, On the Origin and History of the Runic Script: Typology and Graphic Variation in the Older Futhark (Stockholm: Almqvist \& Wiksell, 1990) 63-6; Gaby Waxenberger, "The Inscription on the Gandersheim Casket and the Runes in the Old English Runes Corpus (Epigraphic Material)", Das Gandersheimer Runenkästchen, ed. Regine Marth (Braunschweig: Herzog Anton Ulrich-Museum, 2000) 91-104, at 93-4. 
across the main stave, just as on runes 12 and 24, and it may be suggested that the inscriber simply failed to lift the cutting point fully from the metal after forming the main stave, and rather traced across the surface over to the point from which the crossing by-stave was then cut more firmly, back from right to left and sloping downwards.

Rune 15 , identified as $\mathbf{b}, \vec{B}$, might be the rune $\mathbf{w}, P$. Of the lower triangle that forms a b-rune, the bottom by-stave is quite clear but its upper counterpart is faint at best and can only tentatively be made out under the microscope.

Rune 17, p, p, has lost the lower by-stave to corrosion. However the only alternative rune-form for the staves visible here would be an $\mathbf{n}$-rune that had not been reversed as 12,13 and 24 are, so this identification can be made with confidence.

Rune $21, \mathrm{~s}, 4$. Although this area is badly corroded, this is the only possible identification for the two vertical staves, neither full-height, that are visible here. This s-rune is identical in form to rune 5 .

Runes 26-30, a w r a t. These final five runes are more faintly inscribed than the rest of the inscription, and the area is also quite seriously affected by corrosion. Rune $26, a, F$, is faint but fully visible under the microscope. The upper half of rune 27 is clear but could be from either $\mathbf{b}$ or $\mathbf{w}, B$ or $P$. Only the upper part of rune 28 can be seen, too; however the descending by-stave to the right of this is starting to curve in a way characteristic of the r-rune, $R$, rather than of $\mathbf{u}$ as formed in this inscription (nos. 10 and 18). Of rune 29 only the upper ends of the two upright staves are clear, but the angled joining by-stave of the a-rune as formed elsewhere in this inscription (nos. 20 and 26) can be made out under the microscope. It is possible that this was an o-rune, $F ; h, H$, is also conceivable but very unlikely. Although partly confused by scratches, rune $30, t, \uparrow$, is perfectly clear under the microscope.

\section{The IDentificaton OF ${ }^{\mu}$}

The interpretation of the rune-form appearing at positions 4, 16 and 25 requires more extensive discussion. We can be confident that the form of this rune as ${ }^{\top}$ ' is correctly identified. None of these three graphs is significantly obscured by corrosion, and its distinct combination of a main vertical stave with symmetrical by-staves to both left and right occurs three times over. Although not all of the staves are perfectly joined in every case, in an inscription of this size this is insignificant, and is a feature of other runes in the inscription, too. The spaces between separate runes in the inscription are much clearer than any gaps between the staves of these runes, so one cannot argue that this unfamiliar form is merely the product of a misleading juxtaposition of otherwise separate runes.

$\Psi$ has not been seen before as a separate rune in an inscription. It is similar to the historical rune $\Psi$ that was a graph of the original fupark, where it appears to have had the name "algiz, 'elk', but the phonetic and phonemic value of its final consonant, $[\mathrm{z}]$ (which became the palatal $\mathbf{R}$ of 
Proto-Old Norse). ${ }^{6}$ This rune is extremely rare in Anglo-Saxon runography, although it does appear in its normal place in the fuporcs on a pinhead from Brandon, Suffolk, and the London Thames scramasax. The Brandon Pin can be dated to the later eighth or early ninth century while the London Thames scramasax is probably ninth-century, possibly even later. ${ }^{7}$ The rune $\Psi$ also appears in the runic chi-rho monogram on $\mathrm{St}$ Cuthbert's coffin of AD 698 in the place of Greek x.

It subsequently appears in a series of runic alphabets (not fuparks) in Continental manuscripts dating from the late ninth to the twelfth century and later, intended to illustrate a treatise on the invention of letters (De inventione litterarum). Here indeed it does have the form ${ }^{\top}$ and is given as the runic equivalent of Roman $\langle x\rangle$, together with the name halech: a plausible if imperfect reflex of the original "algiz, OE *eolh/*iolh. ${ }^{8}$ It is widely accepted that these manuscript runes are heavily affected by early medieval scholarly fabrication, attempting to assimilate diverse writing systems to a single scheme. ${ }^{9}$ David Parsons, indeed, argues that as early as the late seventh century, on St Cuthbert's coffin $\Psi$ was used to represent Roman $<\mathrm{x}>$, which was equated in turn with Greek $x$, because the latter graph was now needed in England, while the rune $Y$ was redundant in its original value in Old English, $[\mathrm{s}]$ and $[\mathrm{z}]$ being allophones. ${ }^{10}$ It is proper to note, though, that the consonant sequence [ks] was not entirely stable in Old English, and quite frequently appears as $-h s$ - in Roman script; ${ }^{11}$ employing the soundvalue of the final consonant, as in "algiz/*elgR for $\mathbf{z}$ or $\mathbf{R}$, " $e o l b$ is not an inappropriate choice for Roman $\langle\mathrm{x}\rangle$, and certainly not for Greek $\mathrm{x}$.

Transliteration as $\mathbf{x}$ representing either $h s$ or [ks] is not meaningful in the Baconsthorpe inscription, however, and there is a better alternative to be proposed. Although not hitherto identified as a distinct grapheme, the rune-form ${ }^{\top}$ ' is also already known as part of a bind-rune with the e-rune at the beginning of a moneyer's signature on coins of the reign of Offa of Mercia (757-96). This moneyer's name has been read as Eadnop, with the

${ }^{6}$ Odenstedt 1990, 83-6; Terje Spurkland, Norwegian Runes and Runic Inscriptions (Woodbridge: Boydell, 2005) 7; Hans Frede Nielsen, The Early Runic Language of Scandinavia: Studies in Germanic Dialect Geography (Heidelberg: Winter, 2000) 33-4, 41-51 and 63-70.

7 Raymond I. Page, An Introduction to English Runes, 2nd ed. (Woodbridge: Boydell, 1999) 80-2; Brandon: The Making of England, ed. Leslie Webster \& Janet Backhouse (London: British Museum, 1991) 82, no. 66b; Thames scramasax: The Golden Age of Anglo-Saxon Art, eds. Janet Backhouse et al. (London: British Museum, 1984) 101-2.

8 René Derolez, Runica Manuscripta: The English Tradition (Brugge: Rijksuniversiteit te Gent, 1954) esp. 360, 369-70; Page 1999, 71.

9 This was carefully discussed by Wilhelm Carl Grimm as early as 1821: Ueber deutsche Runen (Göttingen: Dieterische Buchhandlung, 1821) 79-157. My thanks to Professor Klaus Düwel for drawing my attention to this discussion.

10 Parsons 1999, 90-4; cf. Campbell 1959, $\$ 50$ (1).

11 Campbell 1959, SS 53, 416 and 440. 
suggestion that the second element of the bind-rune, which we see here as a separate grapheme, is the ea-rune, $\uparrow$, inverted. ${ }^{12}$ A modified interpretation takes account of formal relationships within the Anglo-Saxon futhorc, but gives equal weight to the lexical, morphological and syntactic interpretation of the Baconsthorpe inscription as transcribed above. If the second element in the bind-rune on the coins is identified as ea then not only will the moneyer have turned this rune upside down to form the bind-rune but he will also have needlessly created a bind-rune of e/ ea to represent the diphthong ea that is already fully represented by just one of the elements of that bind-rune. That is presumably quite possible had he wished to write his name with an ostentatious flourish, but it is systemically redundant if so.

The new evidence may lead us to a more satisfactory solution. The similarity of ea, $\uparrow$, and the new rune $\uparrow^{\top}$ is undeniable. At the same time, grammatically the ideal phonemic value for the new rune in the $\mathrm{Ba}$ consthorpe inscription (explained immediately below) suggests that the form may indeed have been devised as a direct counterpart to ea, and that it functions in a sophisticated way as a simple inversion of that rune. It was not produced in order to represent an inverse diphthong ae, which did not exist in Old English, but rather to represent the monophthong that was often graphically represented by <ae> in the earliest Old English written in the Roman script. ${ }^{13}$ This is the vowel conventionally transcribed as $\infty$ and $\bar{\infty}$ in standardized edited versions of Old English text. Following Henry Sweet's practice, and for ease of reproduction in word-processed and printed text, ę is proposed as the appropriate transliteration here, so as to maintain a distinction from $\mathfrak{x}$ as the transliteration of the different and familiar rune $\mathrm{f}$, asc. For the signature on the coins, then, a correct transliteration would be e/ę $\mathbf{d} \mathbf{n} \mathbf{o} \mathbf{p}$, implying that the equivalent in standardized Roman script would have been Exdnop. A spelling of ece for the reflex of Germanic $a u$ is otherwise found only in very late (eleventhcentury) Old English; early variant spellings recorded by Campbell always have <ae> or <æ> as the first element: aea, aeo, $e_{0}$ and $\propto u .{ }^{14}$

The present author recently argued in another context that the extensive shifts in the vowel system of early Old English led to greater variety and experimentation in the representation of vowels in Anglo-Saxon runic writing than had previously been recognized. ${ }^{15}$ The Baconsthorpe inscrip-

12 Charles Blunt \& Gay van der Meer, British Numismatic Journal 38 (1969): 1823; Mark Blackburn, "A Survey of Anglo-Saxon and Frisian Coins with Runic Inscriptions”, in Bammesberger 1991, 137-89, at 160; Parsons 1999, 1, 83-4; Mindy MacLeod, Bind-Runes: An Investigation of Ligatures in Runic Epigraphy (Uppsala: Institutionen för nordiska språk, 2002) 86-7.

13 Campbell 1959, $\$ 40$.

14 Campbell 1959, $\mathbb{S}$ S 136, 276 and 278.

15 John Hines, "The Early Runic Inscriptions from Kent and the Problem of Legibility", Das fupark und seine einzelsprachlichen Weiterentwicklungen, ed. Alfred Bammesberger \& Gaby Waxenberger (Berlin: de Gruyter, 2006) 188-208. 
tion, with its ę-rune $\psi^{\uparrow}$ supports that view. In this text, the co-occurrence, and indeed collocation, of $\underset{e}{ }$ and $\mathfrak{x}$ show that ę was not just a local substitute for or equivalent of $\mathfrak{x}$. This implies that although the origin of the vowel spelt with ę in [æ] was recognized - and it is quite possible that that articulation was still preserved in special circumstances of careful pronunciation and emphatic speech - ę represents [ə] or a phoneme converging on [ə]. This would be remarkable as a grapheme representing a phoneme that occurs only in unstressed positions. ${ }^{16}$

\section{From Transliteration to Translation}

If correctly read, the Baconsthorpe inscription is syntactically perfectly formed in two sentences. In standardized Old English spelling, the first of these is Rèdoe sē pe cuinne (which might be normalized as Rèdoe sē pe cynne): 'Read whoso may'. The verb rédan will show the $\bar{e}$ for Germanic $\bar{a}$ characteristic of Anglian and Kentish as opposed to the West-Saxon dialect of Old English, where the reflex of this long stressed vowel was $\bar{\propto} .{ }^{17}$ A 'polite' imperative is formed of the 3rd person singular present subjunctive, i.e. 'let him read', followed by the relative pronoun (masculine for a common animate gender). Close and significant parallels to this formula occur in Exeter Book Riddles 59 and 67: Réde sē pe wille ('Read whoso will') and Secge sē pe cunne ('Say whoso may') respectively.

It was noted above that the identification of runes 9-13 is problematic, and the suggested reading, cuinne, is slightly unexpected from a runological perspective in that the use of a doubled graph $<\mathrm{nn}>$ to represent a long consonant [n:] is regular in Roman script for Old English but not in the Anglo-Saxon or any other runic tradition. This word, like rédoe, should be the 3rd person singular present subjunctive, and the familiar form of this part of the paradigm of the Old English verb cunnan is cunne; where we might expect, then, the same inflexional vowel as with rédan. However a 3rd person singular present subjunctive cyme in the aorist-derived present tense of the complex Class IV strong verb cuman indicates that preteritepresent verbs such as cunnan could form their present subjunctives with a thematic vowel $-i$, which was lowered to $-e$ after causing $i$-umlaut, rather than Germanic -ai, which yields $\bar{a}$ and $\overline{\alpha e}$, which eventually shortened to $\alpha$ in unstressed position and itself finally levelled to $-e$, in turn. ${ }^{18}$ In this case the vowel sequence <ui> would represent the mutated vowel [y]. ${ }^{19}$ The doubled consonant nn implies that the inscriber - perhaps unconsciously -

16 Gaby Waxenberger, "The Representation of Vowels in Unstressed Syllables in the Old English Runic Corpus”, in Alfred Bammesberger \& Gaby Waxenberger 2006, 272-314.

17 Campbell 1959, $\mathbb{S} \mathbb{S} 128-9 ;$ Hogg 1992, $\mathbb{S} \mathbb{S} 3.22-25$.

18 Campbell 1959, \ 742.

19 Campbell 1959, \ 42 and 199. 
followed standard Roman-script spelling practice rather than runic for this word.

The reading proposed for the second sentence, in a standardized edited form, is Bēaw pās rünce āwrät: 'Bēaw inscribed these runes'. pās rünce is grammatically unproblematic: a nominative or accusative plural noun phrase which, like the first sentence, refers directly to the inscription itself. It is acknowledged that the reading of the less clear runes 26-30 at the end of the text as āwrāt is influenced by an anticipation that such a verb, the 1 st or 3 rd person singular preterite of awritan, 'to write down/inscribe', will appear here; however the inscription has been very carefully scrutinized to test this idea. Everything that can be seen of the runes is fully consistent with this interpretation, even though only the initial a and final $\mathbf{t}$ can be seen in full, with the aid of a microscope.

If this reading is correct, then the sequence transliterated $\mathbf{b}$ e $\mathfrak{x} \mathbf{u}$ at the start of the sentence should be the subject of the verb. The best identification appears to be the word beaw, recorded in a handful of glosses as the Old English equivalent of Latin oestrus, 'gadfly', or cretabulus, an otherwise unexplained word that occurs only in these glosses. Béaw is also known as a place-name element. ${ }^{20}$ This could have been used as a personal name or nickname. It is famously once recorded as a personal name, in the West Saxon royal genealogy found in the Chronicle and Asser's Life of Alfred. ${ }^{21}$ Evidence of its use in East Anglia may reside in the placename Bawsey, recorded in the Domesday Survey of 1086-7 as boweseia, a site of historical and archaeological importance, also in Norfolk, close to King's Lynn. ${ }^{22}$ Again, however, the spelling raises questions. The imperfect initial $\mathbf{b}$ has been noted and discussed above. If the presence of the postulated ę-rune $\Psi^{\top}$ implies familiarity with the ea-rune, $\uparrow$, we might expect the latter to have been used here for the diphthong $\bar{e} a$. Final $\mathbf{u}$ rather than $\mathbf{w}$ is in itself no great problem or surprise, as the rounded vowel $[\mathrm{u}]$ and bilabial semivowel $[\mathrm{w}]$ are phonetically highly proximate. ${ }^{23}$ Here, however, it may help us to an explanation. In the other two locations in this inscription, ę represents an unstressed vowel which was originally [æ] but which by now may have shifted almost universally to [ə]: it seems possible, then, that the inscriber interpreted a name that phonemically we

20 DOE: Dictionary of Old English in Electronic Form, ed. Angus Cameron, Ashley Crandell Amos \& Antonette diPaolo Healey (Toronto: Centre for Medieval Studies, 2003) [CD ROM publication], s.v. beeaw; Albert H. Smith, English PlaceName Elements, 2 parts (Cambridge: English Place-Name Society) Pt. 1, 23, s.v. bēaw.

21 Parker Chronicle, s.a. 855; Mats Redin, Studies on Uncompounded Personal Names in Old English (Uppsala: A.B. Akademiska Bokhandlen, 1919) 26.

22 Andrew Rogerson, "Six Middle Anglo-Saxon Sites in West Norfolk", Markets in Early Medieval Europe, ed. Tim Pestell \& Katharina Ulmschneider (Macclesfield: Windgather, 2003) 110-21, esp. 112-14; Tim Pestell, Landscapes of Monastic Foundation (Woodbridge: Boydell, 2004) esp. 31-3.

${ }^{23}$ Campbell 1959, $\mathbb{6} 60$. 
would analyse as /bæ:əw/ as being constructed rather of the sequence /bə/ followed by $/ \mathfrak{x}(:) \mathrm{w} /$ or a diphthong $/ \mathfrak{x}(:) \mathrm{u} /$. The variance in the early spellings of this diphthong has already been noted. e/ędnop remains curious: in this case the first element is clearly identified as $e$, as became standard in the Roman-script spelling of the reflex of this diphthong, even though it is widely believed that the pronunciation of the first element remained low and open. ${ }^{24}$ It might have been analysed as [eæ] and [eə] in careful and more relaxed pronunciation respectively.

\section{Dating and Provenance}

The 'Eadnop' coins are very helpful in dating the Baconsthorpe inscription. They are light broad-flan pennies, dated in the reign of Offa between his conquest of East Anglia in the 760s and a revision of the weight-standard to a heavier penny of AD 792. Of the four known coins of Eadnop, one is from Burgh Castle, Norfolk, and one from the Norfolk/Suffolk border. The most recent find is from Chiselden, near Swindon in Wiltshire within Offa's territory. The first coin example found was in fact from the trading site or wic of Dorestad (Wijk bij Duurstede) in the Netherlands: a site whose long-distance trading connexions, including East Anglia and the Upper Thames region, were extensive. ${ }^{25}$ The use of runes for legends on coins would also appear to have been a strongly East Anglian tradition. ${ }^{26}$ The rarity of the ę-rune $\Upsilon^{\top}$ suggests that this rune was in use for only a limited period and in a restricted area. We can therefore propose a date-range of $c$. AD 750-800 at the broadest for the Baconsthorpe inscription.

\section{DisCusSION}

To review the implications of the interpretation of the Baconsthorpe inscription as it has been read here, it seems most appropriate to start with its remarkably literary character. The text appears to be thoroughly autoreferential, referring both to its own reading and writing through verbs

${ }^{24}$ Campbell 1959, $\mathbb{S} \mathbb{S} 37$ and 40; Hogg 1992, $\mathbb{S}$ 2.20-29.

25 Arguments for a narrower dating of the 'Eadnop' coins to the period c. AD 780/ 5-792/3 were published after this article was submitted: Derek Chick, The Coinage of Offa and his Contemporaries, eds. Mark Blackburn and Rory Naismith, British Numismatic Society Special Publication 6 (London: Spink, 2010) 1-15 and 133-4. These would justify us narrowing the suggested date-range for the Baconsthorpe inscription to the last quarter of the eighth century.

26 Blackburn 1991, 146-9; John Hines, "Coins and Runes in England and Frisia in the Seventh Century", Frisian Runes and Neighbouring Traditions, eds. Tineke Looijenga \& Arend Quak, Amsterdamer Beiträge zur älteren Germanistik 45 (1996) 47-62. 
which lie alongside one another as it has been laid out. At the same time, the inscription draws attention to its own specifically runic character. Lexically, this text provides not only interesting but important new information on the terminology of literacy at a particularly early date. It contains three terms that are used in senses indistinguishable from their modern derivatives, 'write', 'rune' and 'read'. Since these concern a runic inscription, it is appropriate first to consider the word runnee in this text.

There is solid evidence in archaeologically datable runic inscriptions from Germany and Scandinavia that the feminine noun rūn was used from the sixth century at least precisely as we would use it: to refer to the graphs of the runic fupark. Four sixth-century pre-Old High German inscriptions, two on brooches, one on an ivory ring and one on a wooden stick, combine it with the verb 'wrote' in the phrase uraitruna or wrætruna, in which runa is the expected accusative plural of a feminine $\bar{o}$-stem noun. ${ }^{27}$ The earliest Scandinavian evidence is the forms runaz/ronoz (acc. pl.) and runo (gen. pl.) from a small group of seventh-century runestones in Blekinge, Sweden, and a further runestone from Gavendrup, Fyn, Denmark, dated to c. AD $900 .{ }^{28}$ Old Norse eddic poetry, particularly Sigrdrifumál and Rígspula, contains numerous references to various, probably very imaginary, uses of runes using precisely the term rún, but it is difficult to be sure just how early any of those instances might be dated.

In the case of Old English, however, the picture has been rather distorted by the fact that the two most relevant discussions, by Ray Page and Christine Fell, ${ }^{29}$ were primarily concerned to explode the notion that runes had deep historical associations with magic and mystery. They emphasized instead the semantic range of the lexical root, and its frequent association with knowledge and the power that knowledge can yield, and largely dismissed the identification of runic script with the word rumn. Page was justified in observing that "the connexion [of the words rün and gerȳne] with written or inscribed characters is tenuous", ${ }^{30}$ but even though the evidence for the early use of the word in precisely this sense in cognate Germanic languages has grown considerably since the early 1960s, he might have attached more weight to the fact that OE rünstafas clearly denotes runic letters (possibly as opposed to the bōcstafas of Roman script) in two of the Exeter Book Riddles. ${ }^{31}$ It is impossible to insist that runstafas always unambiguously denotes 'runic characters' rather than, possibly, 'arcane letters'; in the Baconsthorpe inscription, however, the probability

27 Klaus Düwel, Runenkunde, 4th ed. (Stuttgart: Metzler, 2008) 57-9.

28 Nielsen 2000, 95-100.

29 Raymond I. Page, "Anglo-Saxon Runes and Magic", Journal of the British Archaeological Association, 3rd Ser. 27 (1964): 14-31; Christine E. Fell, "Runes and Semantics", in Bammesberger 1991, 195-229.

30 Page 1964, 20; quoted by Fell 1991, 199.

31 Riddles 42 and 58, where rünstafas refers to runes identified in the extant texts by name rather than by symbol. 
that $p \bar{a} s$ rūnce means 'these runes' is overwhelming. The only alternative, in the case of the present inscription, is that runce refers to the profound information within the putative book for which this might be a page-turner or holder, and of which Bēaw must then have been the scribe. It is much more tempting to entertain the idea that any such manuscript's scribe and the inscriber of the runes could have been the same individual (Bēaw), and that runce cleverly refers both to the runes and the contents of a codex - but that, of course, is far beyond any form of test.

As the sixth-century pre-Old High German inscriptions referred to above indicate, the verb writan was also a widespread and even standard term for the writing of runes. In early Scandinavian runic inscriptions it appears on the sixth-century Eikeland brooch from Rogaland in Norway, while the seventh-century Istaby runestone in Blekinge has the sentence hApuwulafz ...warAit runAz pAiAz: ${ }^{32}$ 'Hapuwulf ... wrote/carved these runes'. This is a verb whose primary sense was 'to scratch' or 'to incise': the sense retained by German ritzen. By the Viking Period it had been superseded in Proto-Old Norse as the term for carving runes by the apparently related verb rísta. In Old English, the verbs wrìtan and äwritan became entirely standard for writing in any medium; the written text, concomitantly, is gewrit. This is the root that has survived as the lexical base term of contemporary English. Although Gothic has a related noun, writs, for a small written mark, in all of the other Germanic languages the verb adopted for the writing of the Roman script was the Latin loanword scribere. $^{33}$

Another key term with which English has followed a different path of lexical development from all the other Germanic languages is in the verb 'to read', from a Common Germanic "rēðan. All of the other languages use the verb lesen (lezen, lese, lesa, läsa, etc.), apparently adapting a verb meaning 'to gather' under the influence of Latin legere. ${ }^{34}$ The Old Norse cognate of $\mathrm{OE}$ rēdan/rēdan, ráda, is, however, used in the sense of reading specifically in collocation with rúnar, partly, no doubt, under the influence of alliteration. The semantic core of this verb appears to have been a sense of 'to interpret', with the connected senses of 'to advise' and further 'to govern' (cf. modern German raten, Danish råde, etc.).

As in the case of writtan and āwritan, Old English had a pair of verbs, rēdan and arexdan. The prefix $\bar{a}$ - seems to have had little semantic force. In the case of $(\bar{a})$ rexdan, though, the emergence of a dominant sense of 'to read' (i.e. to construe and comprehend written text) is slower, and less

32 The difference between a and $\mathbf{A}$ in transliteration here is that between an original a ("ansuz) and an innovation A (ár < *jāra): Michael Schulte, "Älteres und jüngeres Fupark-phonologische Aspekte der Reduktion des Runenalphabets", in Bammesberger \& Waxenberger 2006, 414-33, at 419-20.

33 Dennis H. Green, Language and History in the Early Germanic World (Cambridge: Cambridge UP, 1998) 262-4.

34 Green 1998, 264-5. 
exclusive than the redeployment and eventual restriction of writtan and awwritan to the semantic field of literacy. The earliest unambiguous examples of rēdan and àrōdan in the literate sense of 'to read' appear to be in Prologues to Alfredian translations: $p \bar{a} b \bar{o} c$ reeden in the Proem to Boethius, and gewrit ar $\overline{r e d a n}$ (twice) in the Preface to the translation of the Cura Pastoralis. ${ }^{35}$ Earlier in the ninth century, examples of àrédan/ areedan tend to imply rather a sense of 'to read out loud from a text': for instance in the grant of the Ealdormann Oswulf to Christ Church, Canterbury, dated 805-10, the condition that àeghwilc diacon àrēde twā passione fore his sawle, 'each deacon should read out two passion-narratives

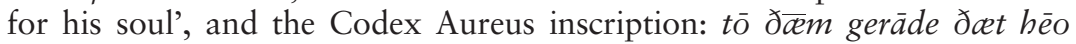
mon àrēde èghwelce mōnaðe ... hèora sāulum tō ècum lècedōme, 'on the condition that it is read from every month for the eternal salvation of their souls, ${ }^{36}$

In the Baconsthorpe inscription, it is certainly both possible and valid to construe the first sentence as 'Interpret this whoso may'/'Make sense of this, whoever can', rather than just 'read this whoso may'. Yet since this sentence manifestly refers to a written text - be that the immediate runic inscription of which it is part, the putative book it may be associated with, or both at the same time - it clearly demonstrates how the semantic development from 'interpret' to 'read' was conditioned by the actual collocation of the term with available texts. The suggestion that an idiom recdan rūne, 'to read runes', parallel to ON ráda rúna, may have influenced this development can neither be promoted nor rejected with confidence. As Svante Norr has shown, the alliterative pairing of $r \bar{x} d$ and $r \bar{u} n$ is well represented in Old English poetry; this is one of the most common alliterative associations for $r \bar{u} n$. These examples, however, involve the nominal form røed ('advice', 'counsel') rather than the verb: rüne arøedan is in fact found only once. ${ }^{37}$ This sort of collocation can only, then, have had a relatively marginal influence on the development of 'read' in the English lexicon.

Dennis Green nonetheless attached considerable importance to his perception that Old English was the only Germanic language "to apply three runic terms regularly to using the Roman alphabet" [stoef, writtan, rēdan] ${ }^{38}$ If the Baconsthorpe inscription really is on a page-holder or page-turner, it illustrates to us perfectly how, in the second half of the eighth century, the practical conditions for this interaction between runic and Roman/Latin traditions were in place, for manuscripts of parchment

35 Dorothy Whitelock, Sweet's Anglo-Saxon Reader in Prose and Verse, 15th ed. (Oxford: Clarendon P, 1967) texts II and IIIA.

36 Whitelock 1967, texts XXXIIIA and XXXV.

37 Svante Norr, To Rede and to Rown: Expressions of Early Scandinavian Kingship in Written Sources (Uppsala: Department of Archaeology and Ancient History, 1998) 115-21.

38 Green 1998, 258. 
or vellum would surely be in the Roman script, and most commonly in Latin. There was a literate community in which two scripts, as well as two languages, were in extensive use. This topic, and the evidence of interaction between the different script traditions, have rightly attracted increasing interest over the past two decades.

The use of runes in the Middle Anglo-Saxon Period (the later seventh to mid-ninth centuries) seems to have taken on a new lease of life under the influence of Roman script traditions and the more literate culture that accompanied the introduction and consolidation of the Christian church in England. Runic practice was directly influenced by Roman norms in ways that have already been noted in this discussion. At the same time, there was decidedly no complete assimilation of practice; and indeed a consciousness of an essential incompatibility between the runic script and its traditional Germanic (including non-Christian) connotations, and the Roman script of Christian Western Europe, must have been a key factor in the demise of the Anglo-Saxon epigraphic runic tradition by the tenth century. ${ }^{39}$ The interpretation of the Baconsthorpe inscription offered here implies that the inscriber had a deep familiarity with the writing of Old English in the Roman script. The one sign that he knew and respected different spelling traditions of the runic script lies in the presence of distinct vowel graphemes ę, $\Upsilon^{\top}$, and $\mathfrak{x}$, $\uparrow$. That he could diverge from these norms and transcribe Roman-script spellings into runes is shown by cuinne, if correctly identified. The explanation of the ę-rune, ${ }^{\psi}{ }^{\prime}$, proposed here also posits a fundamental influence of Roman-script practices on the Anglo-Saxon runic tradition in the eighth century to generate a runic equivalent of Roman <ae>.

This inscription is exceptionally well formed stylistically, as well as graphically and grammatically. Besides the parallels quoted above from the Exeter Book Riddles, Wulfstan of Worcester and York was particularly fond of the formulaic pattern of the first sentence, repeatedly using the clauses gecnāwe sē pe cunne and understonde sē pe cunne. What the inscriber chose to write in the inscription recognizes the 'riddling' or challenging character of any script: reading is an acquired skill which not all possess. Like Wulfstan, albeit on a slighter scale, he was conscious of the superiority and authority his mastery of this mystery imparted. It is the Exeter Book Riddles that may completely dispense with this true gravity, redeploying the phrase in the context of the facetiae of riddles within a community where literacy could be taken for granted. Awareness of these different contexts within which the formulaic clause has been used, and of its quite different tone in each of those contexts, helps to reinforce our

39 Christine E. Fell, “Anglo-Saxon England: a Three-Script Community?”, Proceedings of the Third International Conference on Runes and Runic Inscriptions: Grindaheim, Norway, 8-12 August 1990, ed. James E. Knirk (Uppsala: Institutionen för nordiska språk, 1994) 119-37; Parsons 1999, 85-100, 109-19; Hines 2006, 189-90. 
appreciation of how the convergence of runic and Roman script traditions in eighth-century England was far from a merger. The literate of this cultural context could deploy more than one style, at more than one level, and for more than one readership - and all this, in the eighth century certainly, within a culture that was still predominantly oral. ${ }^{40}$

CARDIFF

JOHN HINES

40 My thanks are due first and foremost to Richard Hoggett of NAU Archaeology, Norwich, and the site-developers, Scira, for bringing the find to my attention, and their interest and support in the preparation of this study. Warm thanks are also due to Dr Tim Pestell of the Castle Museum, Norwich, Professors Alfred Bammesberger and Klaus Düwel, Dr Gaby Waxenberger and Dr Lisbeth Imer for their invaluable suggestions, advice and guidance. Finally, the author's sincere thanks to Dr Svante Lagman, Uppsala University, for his generous assistance in modifying the runic font he had produced to accommodate the newly identified graph. 